This work is licensed under a Creative Commons Attribution 4.0 International License.

Ovaj rad dostupan je za upotrebu pod licencom Creative Commons Imenovanje 4.0 međunarodna.

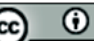

\section{Šimo ŠOKČEVIĆ}

Department of Philosophy and History

Catholic Faculty of Theology in Đakovo

Josip Juraj Strossmayer University of Osijek

Petra Preradovića 17

HR - 31400 Đakovo

simo.sokcevic@djkbf.hr

\section{Tihomir ŽıVIĆ}

Department of Bioeconomics and Rural Development

Subdepartment of Foreign Languages and Physical Education

Faculty of Agrobiotechnical Sciences

Josip Juraj Strossmayer University of Osijek

Vladimira Preloga 1

HR - 31000 Osijek

tihomir.zivic@fazos.hr
UDK 272-732.2 Newman, J.

27-722 Strossmayer, J. J.

322

DOI: https://doi.org/10.29162/ANAFORA.v7i1.11

Izvorni znanstveni članak

Original Research Article

Primljeno 15. siječnja 2020.

Received: 15 January 2020

Prihvaćeno 7. travnja 2020.

Accepted: 7 April 2020

\title{
NEWMAN AND STROSSMAYER ON THE RELATIONSHIP BETWEEN THE CHURCH AND THE STATE (I)
}

\begin{abstract}
The relationship between the Catholic Church and the state, and between the Church and the state in general, is a very topical issue, and theoreticians at the present time provide various models that render assistance to the comprehension of that relationship. The complexity and extensiveness of the problem necessitates that it should be dealt with in two parts (articles). Basically, our objective was to represent the deliberations of John Henry Newman (1801-1890) and Josip Juraj Strossmayer (1815-1905), which we consider to be exceptionally valuable and relevant even today. Through such an analysis, we intended to examine how the deliberations of these two great thinkers of the nineteenth century may contribute to a better cooperation between the Catholic Church and the state in present-day Europe. In this, the first article, in which we deal with Newman's and Strossmayer's perceptions of
\end{abstract}


the relationship between the Catholic Church and the state, at the very outset we feature the context in which Newman and Strossmayer each take a closer look at that relationship. This context is characterized by liberalism, but with numerous negative connotations that suffocate the originally positive meaning of liberalism. A negative context of liberalism is an aggravating circumstance in the comprehension of the relationship between the Catholic Church and the state, and on the other hand, from the position of a modern liberal state, Newman's and Strossmayer's comprehension of history, in whose center is the principle of God's Providence, is also qualified in this way, which simultaneously renders the Catholic Church consistent and authentic, unlike the modern liberal state, which frequently assumes utopian and ideological characteristics. For this very reason, that difference regularly seems insurmountable. Finally, we observe that the issues are additionally complicated by the erroneous notion of the Dogma of Papal Infallibility, which is not understood in the spirit of harmony between the conscience and an Authority.

Keywords: John Henry Newman, Josip Juraj Strossmayer, Catholic Church, state, relationship

\section{Introduction}

The right to religious liberty is considered the basis of any healthy democratic régime. The legal protection of religious liberty varies from one country to the other, so we may speak about a multitude of theoretical models of the relationship between religion (Church) and the state. The relationship of the Catholic Church and the state has been the subject of debate throughout history, but in this two-part account, we would like to tackle contributions in the nineteenth century that seem to be especially pertinent today. Thereby, we think about the deliberations of two contemporaries-the British cardinal and saint John Henry Newman (1801-1890) and the Bosnian and Syrmian bishop Josip Juraj Strossmayer (1815-1905), whose residence was in Đakovo. Primarily, it should be emphasized that Josip Juraj Strossmayer was one of the most well-known Croats in the world, an erudite and theologian, a politician and tribune of the people, an initiator and patron of the most significant national cultural-educational and scientific projects in modern Croatian history, who incorporated all his intellectual and physical capacities in the well-being and prosperity of his nation ("Josip Juraj Strossmayer").

On the other hand, John Henry Newman is one of the most significant persons in the religious history of England of the nineteenth century, whose influence on twentieth-century theology, especially on the Second Vatican Council, 
is immense. Both of these men personally experienced all the gravity and complexity of the relationship between the Church and the state, which only amplifies the relevance of their deliberations on the topic. What is more, we start from the thesis that Newman's and Strossmayer's deliberations on the topic are ahead of their time, and, as such, may be the fundament of a modern, democratic comprehension of the relationship between the Catholic Church and the state. By comparing both men's deliberations and their individual contributions, we will demonstrate why it is reasonable make this statement, and we will simultaneously point out the value of Strossmayer's deliberations on the relationship between the Catholic Church and the state, which is still insufficiently explored. In addition, we will try to create a synthesis of Newman's deliberations on the topic, for they are unsystematic, that is, Newman tackles the problem dispersedly, at different places, and in different contexts.

\section{The Context of Liberalism}

When it comes to the relationship between the Catholic Church and the state, it is also worth perceiving the nineteenth-century context in which Newman and Strossmayer were active, domineered by the philosophies of liberalism and utilitarianism, which have increasingly modeled society and policy. Newman and Strossmayer are both critical toward liberalism, which, though emergent in the age of Enlightenment, assumes its full form precisely in the nineteenth century, when a sense of the transcendent, the eternal, and the unlimited is gradually lost. A certain indifferentism also occurs, even toward common sense. In such an atmosphere, it is not surprising that tensions between the Catholic Church and the state exist, and Newman frequently calls the liberals the imitators of heretic Arianism. An anti-church and anti-Catholic attitude become gradually evident, attacking the traditional social and political order of Christianity created by the church. In this context, Newman opines that the influence of the university is also severely affected in addition to that of the Catholic Church, and that it is necessary to preserve the integrity of both institutions.

One may say that Newman and Strossmayer differentiate two types of liberalism. The first one could be called positive, for it is based on Truth and is propagated by both Newman and Strossmayer, starting from the fact that Christianity is a religion of liberty, from which the criticism of the then ecclesiastical hierarchy is also derived. The second type of liberalism may be called negative, for it inclines toward relativism and alienates itself from Truth. Strossmayer and 
Newman, as well as the ecclesiastical magisterium of the time, were against this form of liberalism, which is problematic, since it misuses its principles (which in principle are good) to block the religious, the ecclesiastical, so as to prevent them from being pronounced in society. In his writings, Newman specifically criticized this negative form of liberalism to demonstrate its roots and goals. Newman's deliberations on the negative form of liberalism are significant, for this is the type of liberalism that is dominant today, and Newman, as early as the nineteenth century, started to point out the signs of ideology in it, because of which it may be also called utopian liberalism. Newman primarily objects to this negative type of liberalism because of its inconsistency and its irreverence toward authorities. Therefore, we will analyze these determinants, which are frequently a polity attribute even today and presented a major obstacle to the development of a high-quality relationship between the Catholic Church and the state in the $19^{\text {th }}$ century as well as nowadays. Objectively, we will try to see why it was so difficult to establish a high-quality relationship between the Church and the state and why it poses a problem to us even these days.

Discussing the roots of liberalism, Newman opines that "Arius was the father of liberalism," having negated a dogmatic principle, and liberalism for Newman is essentially anti-dogmatism (Arians 226-27). Thus, we see that, according to such Newman's logic, the roots of Western liberalism should not be sought in medieval nominalism, sixteenth-century Protestantism, or eighteenth-century rationalism, but rather in an even earlier Christian dogmatics. So, at one point, Newman emphasizes the following: "but I saw clearly, that in the history of Arianism, the pure Arians were the Protestants, the semi-Arians were the Anglicans, and that Rome now was what it was. The truth lay, not with the Via Media" (Apologia 140).

We may say that, through the heresy of Arianism, Newman attempted to realize the error of anti-dogmatism, which reemerges in his lifetime in the form of liberalism and Protestantism. The liberals rejected a dogmatic principle and have thereby actually denied the truth, which is erroneous according to Newman, for the intellect is created for the truth. Therefore, the liberals' anti-dogmatic attitude in the nineteenth century should surprise us, as it pertains to something remembered by history. We will see later that this anti-dogmatic attitude was manifested in the Dogma of Papal Infallibility. However, let us return to Newman's ethical-epistemological treatises for the time being. 
A combination of a correct conviction and action provokes the truth. Thus, when a conviction is true and when an action, or behavior, conforms with this conviction, "an action is the expression of the truth," says Newman (An Essay 90). Consequently, a life's objective should be the acquisition of correct convictions as much as possible and then the performance of actions in conformity with these convictions. An equal situation pertains to language. The words that conform to an authentic conviction are an expression of the truth, and language may express divine ideas. This expression is exactly a Catholic dogma. Newman's combination of logic, cognitive theory, and ethics is exceptionally important and deserves further explication. Namely, one may say that, according to Newman, a search for the truth emanates from an "instinct" and the experience of the intellect itself. ${ }^{1}$

Naturally, many ideas may be erroneous, signifying that they are not in correspondence with whatever is beyond the intellect. Yet certain ideas are very much in correspondence with the material and spiritual archetypes beyond our intellect, and as the intellect is created for the truth, it "instinctively endeavors to separate these veracious ideas from the erroneous ones" (Pattison 145). Thus, each person creates a world of his or her own, a spiritual and a physical one, out of convictions, and everyone is free to make whatever he or she wants out of his or her life, for he or she is free to select his or her convictions. The convictions the intellect construes out of ideas of its own and its perspectives of reality necessarily result in action. In this sense, speech, writing, and thinking are also forms of action. Accordingly, we may formulate as follows: a correct action is formed by a veracious conviction, emanating from pious instincts directed by a correct intellect. If a conviction is erroneous, if the instincts are perverse, or if the intellect is corrupted, an action that follows therefrom will be bad, irrespective of how noble it might appear to someone externally. Good deeds have to emanate from correct convictions. The idea that they "have to" do so is not "mere moralizing" (Pattison 174-75; Šokčević 41-48). ${ }^{2}$

According to Newman, an action disconnected from a correct conviction will be punished sooner or later. An action that is founded on an erroneous conviction, or which does not rely on a conviction at all, is erroneous in the

\footnotetext{
${ }^{1}$ Cf. Robert Pattison, The Great Dissent: John Henry Newman and the Liberal Heresy (Oxford 1991), according to whom the intellect is a "conglomerate of various ideas" (145).

${ }^{2}$ All translations of cited sources were done by the author if this article.
} 
same way as is the view on reality from which it emanates. This is an insultation to the truth, and pursuant to Newman, "the truth always retaliates itself" (Lectures 189). This actually means that history is the agent that eventually avenges the truth. Therefore, as the Arians acted on the basis of erroneous convictions, history condemned them, so an analogous situation may be expected when it comes to liberalism, but also when it comes to all other erroneous convictions, including current ones.

In his inaugural cardinal address, in which he refers to liberalism toward the end of his life, Newman emphasizes that liberalism is problematic, as it implies the following:

$[R]$ evealed religion is not a truth, but a sentiment and a taste; not an objective fact, not miraculous; and it is the right of each individual to make it say just what strikes his fancy. Devotion is not necessarily founded on faith. Men may go to Protestant Churches and to Catholic, may get good from both and belong to neither. They may fraternise together in spiritual thoughts and feelings, without having any views at all of doctrine in common, or seeing the need of them. Since, then, religion is so personal a peculiarity and so private a possession, we must of necessity ignore it in the intercourse of man with man. If a man puts on a new religion every morning, what is that to you? It is as impertinent to think about a man's religion as about his sources of income or his management of his family. Religion is in no sense the bond of society. (Iščekivanje 182)

Precisely due to all these reasons, Newman characterized this negative liberalism as an erroneous freedom of thought, but it does not imply that he has not found a place for a private opinion of each Christian, of course. Anyway, we may observe that Newman devotes attention to the fundamental principles of liberalism in his capital works.

An ardency for the truth and an abhorrence of relativistic approaches to the truth are the fundamental principles in Newman's philosophy and something he uses as a sort of counterargument to the principles of liberalism. They are the center of his philosophy and the essence of a dogmatic principle he appreciates in a special way. These attitudes of his are in complete opposition to that what is taught by negative liberalism, too. Specifically, liberalism rejects religious teachings, qualifying them as superstitions, signifying that the liberals rely on "themselves and on the world" (Newman, Essays 2: 141). In that sense, those who 
"advocate a respect of the right to the freedom of speech and private opinion do not stick to it" frequently, notes Newman (Essays 2: 141). They appreciate "their own private right and nobody else's" (Newman, Essays 2: 141). He stresses that it became popular, under the influence of the Protestants, to contemplate that "the faith is not an act of the intellect, but a thing of emotions, sentiments, affectations" (Newman, Essays 2: 141). A contemplation was developed according to which religion is based on taste and sentiment, without anything objective and with everything subjective in itself. In that sense, even those who had expressed outrage at such a pietism began to embrace the thesis that religion is "nothing more than a necessity of human nature, that it is not an objective, external fact and a God's deed" seriously (Newman, Essays 2: 141). Naturally, a thesis that each man's or woman's religion ensues from his or her own needs allows skeptics to question the motives of belief.

Newman realizes that it is precisely liberalism that is coincident with these Protestant deliberations, whereby liberals opine that each man or woman has a right to confess and teach what he or she considers veracious and what is in conformity with his or her conscience, which renders him or her responsible to the truth of his or her religion, of course. Nonetheless, Newman understands this "personal judgment" as a form of "inconsistency" exactly among the Protestants because he deems that a mere judgment of their own or of anyone else's is significant to the liberals and the Protestants. ${ }^{3}$

To Newman, liberalism is especially problematic, for it, as he claims, "tolerates everything because it believes in nothing" (Newman, Historical Sketches 1: 88). It is "weak," for it relies only on "mere opinions," which are to be tolerated, and this tolerance creates "the greatest possible sin when it comes to the truth, being the sin of emptiness," because of which an action becomes absurd, as it is separated from dogmatic convictions (Newman, Historical Sketches 1: 88). One might say that that is the essence of "inconsistency" about which Newman speaks. Generally, according to Newman's opinion, a culture that is founded on erroneous convictions, which then result in erroneous action and in the aforementioned "inconsistency," is destined to perish. In other words, only a culture

\footnotetext{
${ }^{3}$ More about this is perusable in John H. Newman's work An Essay on the Development of Christian Doctrine, published in 1878 (325), his work The Via Media of the Anglican Church: Illustrated in Lectures, Letters, and Tracts Written between 1830 and 1841, published in 1877 (22, 91), and in his Fifteen Sermons Preached Before the University of Oxford between ad 1826 and 1843 (297). This also partly explains his approximation to Catholicism that followed later.
} 
that is based on the veracious convictions may expect the continuation of its existence. According to Newman, there is only one system of beliefs of this kind, and that is Catholicism, and it may withstand the vicissitudes of time alone.

A key difference between the liberals and the believers-the Catholics-lies in the fact that a liberal feels a sense of liberty to form his or her Private Judgment on any assertion of the dogma or of the revelation. On the other hand, a believer strives to seek out an adequate Authority to whom he or she may incline in that sense. In this way, while a liberal penetrates into the issues that transcend the scope of his or her capabilities, a believer bases his or her judgments on the historical evidence of Authority, such as consistency and the integrity of development of an individual doctrine, and on an epistemological relationship of the dogma toward the nature of the human intellect. For example, the liberals reject the dogma on the Holy Trinity because they consider it logically absurd while, on the other side, a believer humbly abides by this dogma due to the respect and esteem of the Church Authority. Newman elaborates this attitude in the work An Essay in Aid of a Grammar of Assent in detail, where he demonstrates that all safety concerning various domains is logically dependent on probabilities, and many propositions that the people consider veracious are in fact founded on a form of confidence or on an Authority we believe in. Consequently, a Catholic retains the faith that something is true although that something cannot be clearly proven. "Faith is an intellectual act, its object is the truth, and its result is knowledge," says Newman (Idea 30).

That liberalism opposed by Newman is indubitably an ideology, being probably most clearly manifested in the aggressiveness it demonstrates. Specifically, numerous liberal principles, both in Newman's and Strossmayer's times and currently, have the task of removing and rejecting religion. Thus, a clear and unambiguous stance is to be taken towards such a liberalism. Explicitly, such a liberalism is an ideology, and both Newman and Strossmayer keep their distance from it. Nevertheless, as stressed before, there is also a positive form of liberalism that is interconnected with Newman and Strossmayer, one which is based upon Christian values.

Thus, one would say that a liberalism that has been closely linked to utilitarianism, rationalism, and relativism may be difficult to dub as liberalism, since liberty, which should be the backbone of such a liberalism is in fact detached from Truth and has thereby vanished, for strict rationality, utilitarianism, and 
relativism do not liberate a human being; on the contrary, they confine him or her within himself or herself. Yet the liberalism represented by Newman and Strossmayer has not been alienated from itself and has not become an ideology. Strossmayer and Newman are aware of numerous values and positive principles of liberalism, like tolerance, democracy, and liberty, which are especially significant for the preservation of society. For them, liberalism is, in a way, a challenge and a sign of the time, so they think that each return to an authoritarian or to a monolithic tradition in this sense would be unrealistic and illogical. In a liberal society, the Church simply cannot afford to be "unliberal." Subsequently, one may say that there is a considerable amount of that what is valuable and veracious in liberalism.

When it comes to Strossmayer's exclusive attitude toward liberalism, one may say that his entire life and activity proceeded between the papal condemnations of liberalism and modernism. Therefore, his stance towards modern society was also significantly modeled by the position of the official Church, but the attitude toward the Popes depended on the way they observed modern phenomena in European society (Slišković 58). In other words, Strossmayer was against a negative form of liberalism and comprehended liberalism correctly, as well as Newman. His orations at the First Vatican Council are very symbolic in that sense, for he "perceives that he has greatly propagated a practice, accepted in the Church nowadays, such as the internationalization of the College of Cardinals, respect and responsibility of the national churches, collegial Church management, ecumenism, vernacular language, and the importance of studies," as noted by Slišković (68). Still, he was naturally aware of the fact that each liberty is limited by Truth and that Truth is the bearer and defender of liberty, which is factually what Newman asserts as well.

In such a context toward liberalism, a special common denominator of Newman's and Strossmayer's ideas pertains to the relationship between science and education. We know that, at that time, conflicts frequently occurred in the field of science, but they are also present today. However, Strossmayer, like Newman, is confident of the compatibility of faith and science and takes a critical stance toward the position of the official Church in this sense while simultaneously moving away from the definition of science present among liberals. Hereby, we would especially single out his effort concerning the erection of educational, scientific, and cultural institutions. For Newman, especially important here is certainly the establishment of both the Birmingham Oratory and the Catholic 
University of Ireland (Šokčević 48-64), while Strossmayer should be mentioned for his care for the schooling of the Bosnian Franciscans in Đakovo, a students' seminary, his magnanimous assistance in the establishment of the Academy and the University in Zagreb, the efforts that he invested in the organization of the Pontifical Croatian College of Saint Jerome in Rome, and the moral and financial support that he gave to numerous high schools and cultural and educational associations. Additionally, Strossmayer rendered his assistance to numerous individuals who have been woven into the fabric of Croatian history, as well, and it is impossible to enumerate them all (Slišković 71).

To a certain extent, Strossmayer and Newman were liberal theologians, too, because both of them indicated that the reasons for the problems the Catholic Church was exposed to should also be sought in the Church itself, not only in the world as such. The members of the Church themselves were liable for the condition in which the Catholic Church found itself due to the simple reason that an Authority is frequently more important than an argument. Therefore, liberalism cannot be opposed by decree and condemnations but only by the truth and consistency, which is given by God, as is the entirety of knowledge. Consequently, the obstacles to a high-quality relationship between the Church and the state also exist within the very Catholic Church itself when it demonstrates its peccable dimension, manifested in the inconsistency and mendacity of individual members. However, this does not jeopardize the fact of its sanctity. Therefore, Newman and Strossmayer oppose the Catholic Church's consistency exactly to the inconsistency and disrespect of authorities by modern liberalism. In other words, in addition to this similar attitude toward liberalism, we would dare say that Newman and Strossmayer are connected by something even more important, being their philosophy of history, which is visibly Christian, Catholic, and reliant on divine Authority and the principle of God's Providence. Through such a realization of history, we observe yet another crucial difference between the Catholic Church and the modern liberal state, which is founded on the principles of negative liberalism, so the reason why it was difficult to harmonize that relationship in the nineteenth century becomes therefore clearer, but this does not make it any easier nowadays.

\section{God's Providence, Authenticity, and the Power of the Church}

In our opinion, Newman's philosophy of history, which he brings forth in the 234 work An Essay on the Development of Christian Doctrine, is a fundament of the 
Christian comprehension of history, as well as of an evaluation of a correct relationship between the state, society, and the church. In that work, Newman asks himself why some ideas are manifested through historical development only. An analysis of Newman's philosophy of history should take into account, that is, the fact that Newman's attitude toward the relationship between the Church and the state, as well as all his life, theology, and thought, may be observed in two phases. The first phase is the epoch when he was affiliated with the Anglican Church, and the second is the epoch when he was a Catholic. In the literature that deals with Newman, Erastianism is generally adduced as one of the reasons for his departure from the Anglican Church. In other words, one of the reasons why Newman abandoned the Anglican Church should be sought in the fact that he had a different view on the relationship between the Church and the state than the one espoused by the official Anglican Church.

Which pattern is common to the various types of developmental social principles (Newman, Essay on the Development 33-41)? While responding to these issues, he emphasizes that our mind develops its thinking solely at a gradual historical pace, so we explore various perspectives by virtue of critical discussion, and we even occasionally incorporate them in visible institutions. Also, there are certain principles according to which we may discern a salutary development from a morbid one.

Thus, he differentiates among seven criteria of healthy development, as follows: "preservation of type," "continuity of principles," "assimilative power," "logical sequence," "anticipation of its future," "conservative action on its past," and its "chronic vigor" (Newman, Essay on the Development 169-443). Newman has shown that these criteria are present in monarchies, economic policies, scientific theories, and in philosophy, but he actually aspired thereby to analogously present the development of Christian doctrine. What has especially enthused him when it comes to the Catholic Church is its fervor and energy to permanently raise itself up restored and refreshed despite the falls. Nonetheless, Newman has not suggested this theory of his pertaining to the development of Christian doctrine as one that will provide a demonstration of Catholicism's value to anyone once and for all, though it does possess all the characteristics of a plausible theory.

Observed in its entirety, this theory, as well as Newman's entire philosophical-theological doctrine, is based upon three principles. These are the princi- 
ple of Providence (all things and events are directed toward an objective - the revelation of God's equity and clemency - and therefore, to be means to live, to develop), followed by the principle of temper (in the sense that God respects the human temper and guides a human being pursuantly), and the principle of analogy (whereby one of the key analogies developed by Newman in An Essay on the Development of Christian Doctrine is exactly an analogy of the natural and of the supernatural, based upon the sacramentality of the cosmos, as well as upon the probabilities in that context, which in turn determine the aforementioned theory's plausibility) (Newman, Essay on the Development 47-48, 85). Newman thus adopts this analogy principle from the Anglican bishop Joseph Butler having primarily perused his work The Analogy of Religion, Natural and Revealed, to the Constitution and Course of Nature.

We will pause to reflect on the first principle noted by Newman, i.e., that God acts in history by virtue of His own Providence. For Newman, this is a fact that cannot be excluded when it comes to the relationship between the Church and the state. Of course, the state does not have to share the conviction that the Providence of God is in action in history, but when it comes to a relationship with the Church, to which Providence is exactly exceptionally significant, the state should respect it. Partially due to this conviction, the Church and the state will always be in opposition, always clearly separated. In other words, belief in God's providential action in history is in fact a differential principle when it comes to the relationship between the Church and the state. Naturally, it does not imply that the Church and the state do not need to communicate, to establish a dialog, due to this difference. On the contrary, this only means that these differences have to be respected if we want this relationship to be healthy and productive.

Strossmayer shares such a comprehension of history, too, and we observe it in two Lenten circulars, one from the year 1886 and the other from the year 1891. The first one was reinvigorated by the Sapientice Christianee encyclical, issued by the Pope Leo XVIII, and the other by the encyclical of the same Pope entitled Immortale Dei, promulgated in 1885. Strossmayer, as well as Newman, speaks about God's Providence in history. He does not penetrate into the philosophical issue of the development of ideas as such, but he speaks from an ideological perspective, maintaining that the Christian truths are pristine, yet always current, clear, and comprehensible. They are eternal, for they are "excerpted from God's being and heart" (Strossmayer 499). God is their "eternal source." They are real 
and always current, for they are "immeasurable and inexhaustible by the being and source of theirs," just as God and His holy being is "immeasurable and inexhaustible" (Strossmayer 499). In this sense, all ages and all peoples may excerpt from these truths what is suitable for them pursuant to genuine necessity and need. These truths are explicit, comprehensible, and their clarity and comprehensibility emanate from the fact that there is an intimate cognation between God and the human being, and in this sense an intimate cognation between "the truth that emanates from God and the human intellect and spirit" is also existent, under the condition that the human soul is pure, innocent, without any infamy and without the infamy of sin, as much as this is possible for a human being (Strossmayer 499).

In this sense, the Church is "the most complete, excellent, exalted, impregnable and divine society in this world," thanks to that everlasting spring of truths (Strossmayer 511). A power that defends the heritage of the divine truths, which "are extended from one part of the world to the other, which are so inalterable that the heavens and the earth will perish sooner than they will," has to be placed in that society, according to its nature, origin, and sacred purpose. (Strossmayer 511). In a certain way, both Newman and Strossmayer would agree that the power of the Church lies exactly in its authenticity and consistency, provided that it relies on the One who is the most authentic and most consistent. Newman will s that authenticity and consistency while comparing his Church to the one of the Church Fathers, especially the Alexandrian ones (Rowlands 186).

In Newman's time, many expressed a certain skepticism when it came to the rehabilitation of the Church Fathers, i.e., for many this was pure romanticism (Rowlands 187). Nonetheless, his treatment of the Church Fathers had a very clear objective, being that of comparison and inspiration. To Newman, the Church of the Church Fathers was actually an authenticity test of his Church, of the Church he belonged to. We may say that he found special inspiration in the Church Fathers, so he frequently asked himself in conflictual situations how the Church Fathers would have acted. The Church Fathers were highly significant for Newman's interpretation of history, because Newman, as a Christian, was aware of the fact that the Incarnation is the central event of time and of eternity. In that sense, a strong invocation of the Church Fathers would be completely comprehensible, since the reality of the Incarnation was most intensively pronounced precisely in their time. Temporally, they were the most proximate to the event, which is actually the most impregnable indicator of God's care for this 
world-the Providence (Rowlands 188). Aware of all of this, Strossmayer introduced the study of patristic literature as part of the philosophical-theological course in Đakovo (within the Theological Seminary) and addressed the importance of patrology in the theological formation of future theologians, as well.

Strossmayer, as well as Newman, strongly emphasizes in many places the theological event of the incarnation of Jesus Christ, who conferred that power of the truth upon the apostolic order, especially upon Saint Peter (Strossmayer 511). Without Christ's incarnation, there is no "eternal salvation, but there is no genuine felicity either" (Strossmayer 511). Thus, Strossmayer stresses as follows: "Jesus is the sun of an eternal justice, which reaches everywhere by its light, and he who rejects it remains in darkness; Jesus is the origin of eternal life, without whom everything bides time in lethargy; Jesus is the way, the truth, and the life. Jesus did not arrive on this world for a single human age only, but for all the ages, not for one generation only, but for all human generations" (61-62). For Strossmayer, a special reflection of God's Providence is also the emission of the Holy Spirit, "who, by virtue of His inspiration, transforms the entire holy ritual and its entire theology, every word and its every act into a pledge of immortality" (62).

This theological truth is actually the main reason why Newman asks himself how much the Church of his time is a perfect icon of God, i.e., how much that Church is in Christ and in God, as the was Church at the time of the Church Fathers (Rowlands 189). This is a specific imperative that he warns against frequently, i.e., that the Church has to persevere upon the apostolic fundaments and has to be tightly bound to the Church Fathers' tradition, and then, inter alia, must also establish its position within society and the state. In that sense, Newman points to an inheritance bestowed upon the apostles, primarily related to the study of a declared truth, but also to Christ's encouragement and his promise that the apostles will have those who will succeed them, too (Newman and Gladstone, Vatican 184-85). Therefore, we repeatedly see how important God's Providence is in this case as well, as the one that ultimately provides for objectivity and guarantees the final definitions or dogmata, i.e. their infallibility.

\section{Infallibility}

In addition to the principle of God's Providence and the very fact of the

Catholic Church's consistency, the Dogma of Papal Infallibility, whose promul- 
gation was a topical issue in Newman's and Strossmayer's time and which both of them accepted, though Strossmayer did not want it to be proclaimed at the First Vatican Council for other reasons, is being imposed as important. Generally, the acceptance of that dogma was accompanied by adversities, primarily because of the context of negative liberalism which we have already discussed. In that sense, for many, that dogma (unjustifiably) poses a "stumbling block" in the relations between the Catholic Church and the state. In that sense, while analyzing a definition of the Dogma of Papal Infallibility, Newman speaks about the difficulties encountered by virtue of faith in relation to the intellect or to an experience, as faith per se demands absolute acceptance. Of course, this absolute acceptance is not always simple, and one has the impression that it is easier to accept certain claims of the intellect or something we arrive on the basis of an experience. The Church, in a way, requires us to believe in certain things without doubt, and this is frequently a problem for the believers themselves, too (Newman and Gladstone, Vatican 183).

Newman brings a theological explication of the dogma based upon a definition that can be found in the Pastor Æternus bull. It is emphasized therein that the Church's infallibility pertains to the fact that the Church as a whole, by virtue of God's mercy (not by the human power of its members), is saved from dropping out of God's truth (and love), and that the ecclesiastical magisterium, by the power of God's mercy, is saved from delusions when it expounds religious doctrines with ultimate commitment. The Church's infallibility originates with the eschatological finality of the salvational situation in Jesus Christ: since God's salvational deed in Jesus Christ is final and victorious, and the truth-the faith-and a socio-ecclesiastical institution belong to its internal constitution, it would be a fallacy to remove it as an imagined self-comprehension of that salvational reality. Besides, it was subsequently defined at the Second Vatican Council as a consensus universalis of the universal Church "in matters of faith and morality," which is "undeceivable," i.e., it cannot err in faith, as it has the magisterium as an organ for the annunciation of that "feeling of faith of an entire people" (Rahner and Vorgrimler 356). Thus, pursuant to the hierarchical structure of the magisterium, the proponents of infallibility are as follows: the entire Church episcopate when it unanimously expounds something mandatory for the Church and for all believers together with its superior, the Pope, under him; a general synod together with the Pope and the Pope individually when he, as the supreme master of the Church (ex cathedra, i.e., with an invocation of his 
supreme Authority of the doctrine), passes a magisterial decision that generally and ultimately obliges. The Pope's final decision is inalterable per se, and not subsequent to the Church's approval, although this does not imply that it should not express the religious conviction of the entire Church.

In his decisions, the Pope is attached to the Scripture, tradition, and former decisions of the Church (as well as the bishops). In his personal attitude and in his private views, the Pope is never "infallible." Above and beyond, an object of infallibility are all the truths (the doctrines on faith and morality) declared by God for His Church of His via Jesus Christ, and, furthermore, all that is necessary to save that truth of revelation from distortions and corruptions (Rahner and Vorgrimler 356).

Speaking of infallibility, Strossmayer cogitates similarly to Newman, which is ultimately also the attitude of modern theology, and so he stresses that eternity is promised and infallibility is bestowed upon the Church by Christ, while its immortality and eternal victory is demarcated by that very same Christ (Matt. 16). For Strossmayer, eternity and infallibility are the internal characteristics of the Church, and they are "the gift of God to the benefit and salvation of all humankind" (514), so the gift of infallibility is a gift for all humanity and for the entire apostolic order, but always connected to its head and crown, i.e., to Saint Peter. Peter is "the crown and the pivot of apostolate, the Chief Shepherd and the father of not only the faithful but also of all the apostles and bishops" (Strossmayer 514).

In that sense, Strossmayer highlights that the Church has referred to the Holy Father since ancient times, so he cites the Church Fathers who spoke about the Holy Father's ascendancy, such as Irenæus, Cyprian, Augustine, Ambrose (Ubi Petrus, ibi Ecclesia) and others. Strossmayer's pastoral stance and actions prior to the First Vatican Council circumstantiate that he had a positive relationship with, or a positive attitude toward, the primacy and magisterial service of the Bishop of Rome. For example, in his analysis of a view on the Church by Josip Juraj Strossmayer, Čečatka stresses that, for Strossmayer, a visitation ad limina signified the rendering of an account for his operation to the Chief Shepherd and judge, the subjection of pastoral premeditations to the infallible judgment of Authority, and an act by which a regional church pledges allegiance, reverence, and obedience to the Holy See. The Bishop of Rome is the Vicar of Christ on the earth; he is the Chief Shepherd, the head, and the fundament of the vis- 
ible Church, the center of the Catholic unity, the oracle of the divine truth, and the leader of the priesthood (Čečatka 208). No doubt, Strossmayer considers the Church to be an infallible teacher and the apostolic magisterium as unique. Therefore, it is understandable that he did not advocate at the Council that the papal supreme magisterial service be determined as personal and infallible, while simultaneously sufficient attention is not devoted either to the magisterial service of the Church as such or to the magisterial service of the Bishop (Čečatka 209). For this reason, he solicited, with a minority, that a new dogma not be promulgated at all, or that it be determined appropriate to the Church organization. He actually sought the best ecclesiological solution to this issue, but this search may be left for some other analyses (Čečatka 209).

What is especially significant to us here is the (actually logical) fact that Strossmayer observes the Church in the same way as Newman does, as permanently identical and inalterable, and he derives that singularity from a similarity of the Church to Christ the Bridegroom, who is equal today, tomorrow, and forever (cf. Heb. 13.8). The internal organization of the Church cannot be decomposed. The Church is interconnected organically; it rests on a vivid mutuality. Each member participates in the gifts of Salvific heritage vested therein, i.e. in the complete life of the Church. Despite the differences between the members, offices, and gifts, none is observed as separated from the integrality of the body of the Church. Also, none is allowed to separate the community of the faithful from the head, or to separate the head from the body of believers. The body and the head are one and live a unified life. Comprehending the Church in this way, Strossmayer says about the gift of infallibility that "the infallibility of the Church and papal infallibility is one and the same" (Čečatka 219). This means that the Holy Spirit inspires both the Church and the Pope. As long as the Church annunciates, proclaims, and interprets the Church doctrine, it always does so via the mouth of the head of the Church, the Pope. Equally, when the Pope, as the head of the Church, proclaims and interprets the doctrine and truths of the faith, he excerpts the eternal truth from the origins of the Church that are inalterable, deriving it from the entire cognizance of the Church, formulated by the Scripture and Tradition (Čečatka 219).

It emanates from the organization of the Church that, when the supreme Authority acts on behalf of the entire Church, it is always visible that the entire body of the Church acts according to it. When the supreme magisterial Authority determines and proclaims an act of faith pursuant to the Scriptures and tradi- 
tion, then it derives the truth from the cognizance of the entire Christian world, e.g. the Dogma of the Immaculate Conception of the Virgin Mary. This is proven by the very procedure by which it is performed. That is, when the supreme Authority attributes and speaks or enacts a law to the whole world on behalf of the entire Church, it does so with an ultimate prudence and forward-looking, so that it is clear to anyone that the very Church speaks and enacts a law (Čečatka 219). In the Church, as apprehended by Strossmayer, anyone participates in the magisterial service and infallibility in his or her own way and to a certain extent. He asserts this primarily because of the patrimony comprising the Word of God and Tradition. That patrimony is vested in the Church, is permanently annunciated, and bears fruits therein; it is adopted by believers, testified, and preserved by all the faithful. Another reason is the ecclesiastical organization, which mutually interconnects all the members of the Church in a single corpus and enables them to take part in the common good. This graduality and hierarchical order was set up by God Himself, and it is stipulated by the ecclesiastical legal code (Čečatka 220).

It ensues from such a perception that it is a right and duty to annunciate, preserve, and defend the truths of the Christian faith, a right and a duty possessed by all the faithful in the Church, including parents, teachers, and children. However, that right and that duty becomes increasingly greater and more efficacious as we approach the higher hierarchical grades and levels. Thus, that right and that duty reach their excellence and plenitude in the Pope, so that all the infallibility of the Church is fluxed and resounded in the Pope, as concluded by Strossmayer. Consequently, infallibility is an exceptional gift of the Holy Spirit and the greatest right that Christ has donated to His Church, and all the faithful participate therein, each one commensurately. Yet, this gift is manifested in Peter and his successors at its most and at its strongest. Thus, when the Bishops of Rome, as the supreme masters, speak with the intention of educating and affirming everyone in the Church in the faith, they are infallible. Since the Bishop of Rome is the Vicar of Christ, the Chief Shepherd, the head of the Church and of the bishops' College of Apostles, it is in him that the eternal power of the Church, and infallibility itself, assumes its divine seal, its supreme confirmation, its strength. And for the same reason, the very bishops' College of Apostles becomes an inseparable and invincible corpus in the Pope and through the Pope. Strossmayer opines that, were the supreme and infallible reputation of the Bishop of Rome be missing in the Church, the very Church system would be 
incomplete and truncated (Čečatka 221). From this, it is visible that one reason why Strossmayer opposed the dogma ensued from a desire to improve relations with the Orthodox, not by the doctrinary reasons. He was afraid that its proclamation would injure the approximation of the Eastern and the Western Church, and that approximation was a lifetime dream of his.

Partly on that track, while contemplating papal infallibility, Newman states that the Pope, as the Vicar of Christ on earth, responds to the conscience, which is the original Vicar of Christ. He emphasizes that the Catholics cannot believe in the Church without believing in the People. In that sense, he stresses as follows:

We must either give up the belief in the Church as a divine institution altogether, or we must recognize it in that communion of which the Pope is the head. With him alone and round about him are found the claims, the prerogatives, and duties which we identify with the kingdom set up by Christ. We must take things as they are; to believe in a Church, is to believe in the Pope. (Newman and Gladstone 99)

Newman quotes that he personally has no problem with the acceptance of the Dogma of Papal Infallibility: "For myself, ever since I was a Catholic, I have held the Pope's infallibility as a matter of theological opinion; at least, I see nothing in the Definition which necessarily contradicts Scripture, Tradition, or History; and the 'Doctor Ecclesiæ' (as the Pope is styled by the Council of Florence) bids me accept it." (Newman and Gladstone 171).

Yet, Newman will specifically stress that the very Dogma of Papal Infallibility is nothing new, since the Pope has enjoyed a similar Authority for centuries, which was only confirmed by the Definition of the First Vatican Council. In other words, the proclamation of that dogma has not changed anything significantly in that sense. Nonetheless, there is one significant segment related to the dogma, being frequently misinterpreted exactly when it comes to the relationship between the Church and the state. It is necessary, namely, to clearly distinguish a spirit of Authority and a spirit of authoritarianism. Otherwise stated, there is an important difference between the concept of Authority in the Church and that of Authority in utopian régimes. In that context, Newman opens yet another important issue, which still construes an obstacle in the harmonization of the relationship between the Catholic Church and the state even today, and that is the issue of conscience and Authority. 


\section{The Relationship Between Conscience and Authority}

Newman presents his attitudes toward conscience and Authority in the debates he conducted with William E. Gladstone and, in the Letter to the Duke of Norfolk (1875), specifically, responded to Gladstone's work Vatican Decrees in Their Bearing on Civil Allegiance: A Political Expostulation (1874). William E. Gladstone (1809-1898) was a British politician and Prime Minister of Great Britain (1868-1874). His religious convictions were a mixture of Anglicanism and Evangelical piety. In 1838, he published the book entitled The State in Its Relation with the Church, in which he defended a theocratic reign model, whereby he emphasized that the Anglican Church is a standard for the relationship between the Church and the state.

This debate of theirs is still very topical today, and the two of them dealt with the issue for almost half a century. The debate actually delineates the full brunt of discussions conducted all over Europe when it comes to the relationship between the Church and the state. It is interesting that Strossmayer also established a correspondence with Gladstone, but on other political concerns (Živić and Šokčević 16). Also, in a correspondence with the Croatian historian and publicist Franjo Rački, Strossmayer refers to Gladstone in different places (Šišić 69, 72, 278). In that correspondence, we may observe how Strossmayer comprehended the relationship between the Catholic Church and the then state in numerous practical issues.

In the text of the Vatican Decrees in Their Bearing on Civil Allegiance: A Political Expostulation, Gladstone fiercely attacks the Roman Catholic Church in certain places. In that sense, he stresses the following:

All other Christian bodies are content with freedom in their own religious domain. Orientals, Lutherans, Calvinists, Presbyterians, Episcopalians, Nonconformists, one and all, in the present day, contentedly and thankfully accept the benefits of civil order; never pretend that the State is not its own master; make no religious claims to temporal possessions or advantages; and, consequently, never are in perilous collision with the State. Nay, more, even so I believe it is with the mass of Roman Catholics individually. But not so with the leaders of their Church, or with those who take pride in following the leaders. (Newman and Gladstone 10) 
We see that Gladstone especially railed against hierarchy, which is also visible in his stance that none can be a proselyte to the Roman Catholic Church without denouncing "the moral and intellectual liberties and surrender[ing] his or her civic loyalty and duty to the other" (Newman and Gladstone 10). Herein, Gladstone is actually thinking of the Pope, who demands absolute obedience, as follows: "[a]bsolute obedience, it is boldly declared, is due to the Pope, at the peril of salvation, not only in faith and in morals, but in all things which concern the discipline and government of the Church" (Newman and Gladstone 10).

In such a context of perseverance upon absolute obedience, Gladstone sees a peril of the Pope's autarchy, for which he cites that it has frequently been demonstrated in history. Additionally, Gladstone also deems the Roman Catholic Church's thesis on constancy (semper eadem) questionable, for which he opines that it was the cause of the Church's forced baptism policy (Newman and Gladstone 12). Nevertheless, when it comes to the semper eadem, we have previously mentioned that Newman assumes that the Catholic Church of that time is the true heiress to the first Church (Newman and Gladstone 92). One may say that this is the fact that has attracted numerous members of the Oxford Movement to conversion. The Tractarians perceived the Catholic Church as a work of God, made and modeled by Christ (Newman and Gladstone 92). Partially due to this reason, it appears ridiculous to Newman to accuse the Catholic Church that it has abandoned the antique legacy, since that very continuity concerning the first Church was the fact that attracted many to convert to the Catholic Church (Newman and Gladstone 94). This is actually the consistency of the Catholic Church we have spoken about previously. Newman opines that if the Church is separated from the state in the sense that the Church is the "Messenger of God," it obliges the state to somehow acknowledge that divine origin to the Church (Newman and Gladstone 94).

In a treatise with Gladstone on the issue, Newman rejects his objection that Catholics cannot be the loyal citizens anymore subsequent to the proclamation of the Dogma of Papal Infallibility, because they have to subordinate their conscience to the Pope. Therefore, it was especially significant to Newman to explain the relationship between the Authority of conscience and the Authority of the Pope. The Authority of the Pope rests upon the revelation that God donated it to him because of His benevolence. God has entrusted His revelation to the Church, and he cares that it has been faithfully preserved and interpreted in the Church and through the Church. When someone accepts this mission of the 
Church in the faith, his or her conscience commands him or her to obey the Church and the Pope as a visible head of that Church. Newman wrote that, if the Pope spoke these words against conscience in a real sense, it would equal suicide. He would lose ground, since his Authority in the theory, as well as his realistic power, actually rely on conscience and on its sanctity. Thus Catholics also listen to the Pope not because someone forces them to do so, but because they believe that God guides the Church and maintains it in the truth through him and through the bishops in communion with him (Geissler 36). The Authority of the Church and of the Pope extends only as much as the revelation and the truth necessary for salvation. There is no harm in repeatedly emphasizing that the decisions related to an ecclesiastical order and administration do not enjoy the right of infallibility. Of course, this is also valid in the event that the Pope takes positions on actual policy.

Gladstone's aforementioned accusations are reemerging today in a similar way when there is a desire for a discrepancy with the Church magisterium to be justified. However, this is completely erroneous, since for Newman, conscience is not a judgment on a speculative truth, on an abstract doctrine, but primarily relates to a behavior, to something that must or must not be done. Newman asseverated that the liberty of conscience cannot be in confrontation with the Pope's infallibility, for conscience is not a judgment on a speculative truth but pertains to governance, to something that should or should not be done hic et nunc. Newman's advice that we should rather listen to a positive and clear dictate of human conscience on an act that should either be performed or missed than to an opposite decree of a superior is not faithful to a lesser extent than a conclusion once derived on the same issue by Thomas Aquinas.

Consequently, conscience cannot be in confrontation with the Church's or the Pope's infallibility. Therefore, the idea that a Catholic may derogate from the Church doctrine in issues of faith or morality because his or her conscience urges him or her to do so should be rejected. He or she will abandon the Church if he or she loses the faith, or if he or she opines, based upon an erroneous conscience, that another faith is veracious. The Catholics' deference to the Pope is not a typhlotic one, but an obedience supported by a pious conscience. The Pope's Authority in that sense is not absolute and cannot substitute the Authority of conscience. Conscience comes first, provided that it denotes an internal human necessity for the truth; then comes the Pope, who represents an $\mathrm{Au}$ thority in the service of the truth. Both authorities, the Authority of conscience 
and the Authority of the Pope, remain connected to each other: the Pope to conscience and conscience to the Pope. Both of them stand for the service of the truth, which eventually is the very Jesus Christ (Geissler 38).

For Newman, conscience is a permanent orientation of a human being to God; it develops in a human being a profound cognizance of God's presence, and it contains a realization that a human being may serve God with all his or her heart, so that service and that orientation to God will be manifested in a coherent behavior of a human being, but it is worth emphasizing that conscience requires obedience. In this context, it seems important to us to explain what conscience means to Newman in several sentences. He ardently believed that conscience is a natural law, a kind of impression of a divine light in a human being, the participation of eternal law in a rational creature, grasped by an individual mind. He is convinced that conscience is the voice of God, not a human creation. Two aspects of conscience are visible in him. On the one hand, there is the dimension of conscience related to moral elements, being actually the particular judgments pertaining to something the people have to or do not have to do, i.e., something that an intellect may develop into an ethical code. On the other hand, conscience is a sentiment of duty applied to these judgments. That second aspect does not rely on itself but concerns something beyond itself. That directs to the One to whom all of us are responsible to. Newman does not perceive a terrestrial persona who could systematically assume that role. Therefore, he opines that conscience should be connected to a supernatural and divine person.

For Newman, God exists because there is moral obligation, whereby he predominantly thinks of conscience. To expound this better, our author warns against a specific feeling manifested when we violate a law that stipulates something. Newman notes that if we delude, if we are immoderate, or if we harbor an egoistic objective, we have a dual sentiment: primarily, that we violate the law, and secondarily that the law stipulates certain provisions. We may alter the second element, but the first one remains. If we realize that our conscience is wrong, we may modify our attitude in some individual situations when it comes to the correct or to the erroneous, but we do not reduce the relevance and the accompanying liabilities of the law while so doing. Conscience is not a law of the intellect but one of the phenomena that effectuates the fact of one's own existence, like a thought or consciousness. Thus, conscience is the recognition of an obligation ensuing from an external being. One may say that conscience, 
according to Newman, provides for a vision and a concrete realization of Providential God, a personal legislator and judge, when it comes to our activity. Consequently, we see that God's Providence is not related to history in a broader sense only, but that it is involved in the lifestyle of each individual who accepts God. Of course, this would be incomprehensible if we were to submit ourselves to God's will without our own temper telling us and dictating to us that it is the right way and that it is good to comply with God and to respect what He obliges us to do in our conscience. On that track, we may say that our primordial religious knowledge emanates from conscience, i.e., we may arrive at a "realistic capture" of God's existence through the awareness of moral commitment.

Yet it is worth emphasizing that this attitude of Newman's about conscience is not his attempt at a formal proof of God's existence as well. Newman is mostly interested in conscience as a dictate. In that context, he stresses that conscience always implies "the recognition of an animate object" (Newman, Essay in Aid $119)$ to which it is oriented. Inanimate things may not agitate our sentiments. An object elicits responsibility in us, we are disconcerted, terrified, etc., before it. These emotions are such because they require an intelligent being as their inducement. In other words, "we develop no emotions toward a stone and do not feel ashamed in front of a horse or in front of a dog" (Newman, Essay in Aid 111-21).

\section{Conclusion}

One of Newman's strongest convictions was that permanent obedience to a righteous, though erroneous, conscience ultimately leads to objective truth (Wright 43). No matter how much conscience may be obscure and instable, it is still a messenger of the one who speaks to us in nature and in grace and affords us leadership via His representatives. It is "the original Vicar of Jesus Christ" (Wright 45). Thus, Authority does not depend on conscience when it comes to the sacred execution of its rights only, it depends on conscience when it comes to a veracious and righteous acceptance, too. An Authority that would not take conscience into account would be suicide (Wright 45). It would destroy itself. A conscience that would not recognize that it needs an Authority, especially a magisterial one, would not accomplish its purpose. Newman's apologetic task sought a reconciliation between the "original Vicar of Christ" (conscience) with the supernaturally illuminated Vicar of Christ in the Church. In view of an in248 fallible doctrine, there are no tribulations, but in special decisions related to the 
political domain, including the facts produced by Gladstone, Newman certainly permits borderline cases, when conscience may be in confrontation with the word of the Pope, and it is better to follow conscience than the word then.

Newman's internal life resulted in his discussion of conscience, and we may simultaneously say that his service in the Church caused him to realistically and respectfully speak about Authority, about the divine and human role of Authority, and even about the uncongenial limits. This vision possibly demonstrates the mutual interaction between conscience and Authority in Catholicism:

Catholic Christendom is no simple exhibition of religious absolutism, but presents a continuous picture of Authority and Private Judgment alternately advancing and retreating as the ebb and flow of the tide; it is a vast assemblage of human beings with wilful intellects and wild passions, brought together into one by the beauty and the Majesty of a Superhuman Power, into what may be called a large reformatory or training school, not as if into a hospital or into a prison, not in order to be sent to bed, not to be buried alive, but (if I may change my metaphor) brought together as if into some moral factory, for the melting, refining, and moulding, by an incessant, noisy process, of the raw material of human nature, so excellent, so dangerous, so capable of divine purposes. (Newman, Apologia 191-241)

The proclamation of the Dogma of Papal Infallibility was interpreted to a considerable extent as an adoption of authoritarianism in the Catholic Church. Nonetheless, the adoption of that dogma is actually an index of harmony between conscience and Authority, of which the state has to take account as well. This precisely implies a respect for the right to the liberty of conscience. However, if the state rests upon the principles of negative liberalism that we have discussed, then it functions upon inconsistency and disrespect for Authority, and is thus actually closed to the appreciation of principles upon which the Catholic Church rests while simultaneously suffocating the right to religious liberty and the liberty of conscience. Still, it is worth emphasizing that the suffocation of religious liberty and the liberty of conscience is a property of totalitarianism, not of liberalism in its true meaning. Contemporary states founded on liberal achievements may indeed find common ground with the Catholic Church, under the precondition that the state Authority is incumbent upon a desire to pass political decisions in the truth. Thus, Newman and Strossmayer 
have already preached understanding and concord between the Catholic Church and the liberal state, which is, as we will see, an optimal model also advocated by modern theoreticians of the relationship between the Church and the state. This is one more reason why we opine that Newman and Strossmayer were ahead of their time in regard to the relationship between the Church and the state, as well as some other issues. We will speak more about that in the second part of the analysis pertaining to the relationship between the Catholic Church and the state from Newman and Strossmayer's perspective, when we will also touch on Strossmayer's attitude toward the relationship between conscience and $\mathrm{Au}$ thority.

\section{Works Cited}

Čečatka, Antun. Viđenje Crkve J. J. Strossmayera (1815.-1905.): perspektive jedinstva sa slavenskim pravoslavnim crkvama. Teologija, 2001.

Geissler, Hermann. “'Savjest je izvorni Kristov namjesnik': pogled na Newmanov nauk o savjesti." Communio: međunarodni teološki časopis, vol. 44, no. 131, 2018, pp. 27-38.

Jeruzalemska Biblija: Stari i Novi zavjet s uvodima i bilješkama iz La Bible de Jerusalem, $7^{\text {th }}$ ed. Edited by Adalbert Rebić et al., KS, 2011.

"Josip Juraj Strossmayer." Hrvatska akademija znanosti i umjetnosti, info.hazu.hr/hr/o-akademiji/osnutak_akademije/strossmayer/. Accessed 20 Feb. 2020.

Newman, John H. An Essay in Aid of a Grammar of Assent. Burns, Oates, \& Co., 1874.

---. An Essay on the Development of Christian Doctrine. Basil Montagu Pickering, 1878.

---. Apologia pro Vita Sua. J.M. Dent \& Sons, 1912.

---. Arians of the Fourth Century. Lumley, 1871.

---. Essays and Sketches. Vol. 2, Longmans Green and Co., 1948.

---. Fifteen Sermons Preached Before the University of Oxford Between AD 1826 and 1843. Notre Dame UP, 1997.

---. Historical Sketches. Vol. 1, Longmans Green and Co., 1908.

---. The Idea of a University. Yale UP, 1996.

---. Iščekivanje Krista: izbor propovijedi. HKD Sv. Jeronima, 2010.

---. Lectures on the Doctrine of Justification. Longmans Green and Co., 1914.

---. The Via Media of the Anglican Church: Illustrated in Lectures, Letters, and Tracts Written between 1830 and 1841. Longmans Green and Co., 1877.

Newman, John H., and William E. Gladstone. Newman and Gladstone: The Vatican Decrees, Notre Dame UP, 1962.

Pattison, Robert. The Great Dissent: John Henry Newman and the Liberal Heresy. Oxford UP, 1991.

Rahner, Karl, and Herbert Vorgrimler. Teološki rječnik. $3^{\text {rd }}$ ed., Karitativni fond UPT, 2009. 
Rowlands, John H.L. Church, State and Society: The Attitudes of John Keble, Richard Hurrell Froude, and John Henry Newman, 1827-1845. 1986. Durham University, Master thesis, etheses.dur.ac.uk/6889/. Accessed 20 Feb. 2020.

Slišković, Slavko. "Strossmayer, Crkva i liberalizam." Book of Proceedings of the $7^{\text {th }}$ and of the $8^{\text {th }}$ Strossmayer Days, edited by Ivica Mandić, Grad Đakovo, 2011, pp. 57-76.

Strossmayer, Josip Juraj. Sve za vjeru i za domovinu. Vol. 2, Đakovačko-osječka nadbiskupija, 2015.

Šišić, Ferdo, editor. Korespondencija Rački - Strossmayer. Vol. 2, JAZU, 1929.

Šokčević, Šimo. Filozofija obrazovanja Johna Henryja Newmana. Biblioteka Diacovensia, 2017.

Wright, John J. Savjest i autoritet. Translated by Marin Srakić, Družba katoličkog apostolata, 1984.

Živić, Tihomir, and Šimo Šokčević. "Strossmayerana in the English Sources: Acton, Gladstone, Newman and Strossmayer." Diacovensia: teološki prilozi, vol. 26, no. 1, 2018, pp. 11-26. 


\section{NEWMAN I STROSSMAYER O ODNOSU IZMEĐU CRKVE I DRŽAVE (I)}

Sažetak
Šimo šoKČEVIĆ
Odsjek za filozofiju i povijest
Katolički bogoslovni fakultet u Đakovu
Sveučilišta Josipa Jurja Strossmayera
Petra Preradovića 17
HR - 31 400 Đakovo
simo.sokcevic@djkbf.hr
Tihomir Žıvıć
Zavod za bioekonomiju i ruralni razvoj
Katedra za strane jezike i tjelesnu kulturu
Fakultet agrobiotehničkih znanosti
Sveučilišta Josipa Jurja Strossmayera
Vladimira Preloga 1
HR - 31 000 Osijek
tihomir.zivic@fazos.hr

Odnos Katoličke Crkve i države te Crkve i države uopće vrlo je aktualno pitanje, pa teoretičari danas podastiru različite modele koji pomažu njegovu poimanju. Složenost i opširnost problema zahtijevaju da se njime bavimo u dvama dijelovima (člancima). Općenito, naš je cilj bio predstaviti promišljanja Johna Henryja Newmana (1801. 1890.) i Josipa Jurja Strossmayera (1815. - 1905.), koja držimo iznimno vrijednima i bitnima i danas. Takvom smo raščlambom nastojali ispitati kako bi prosudbe tih dvaju velikih mislilaca 19. stoljeća mogle doprinijeti boljoj suradnji između Katoličke Crkve i države u današnjoj Europi.

U prvome dijelu, u kojem tematiziramo Newmanovo i Strossmayerovo shvaćanje odnosa Katoličke Crkve i države, na samome početku prikazujemo kontekst u kojem Newman i Strossmayer problematiziraju taj odnos. Taj kontekst karakterizira liberalizam, no s brojnim negativnim konotacijama koje guše njegovo izvorno pozitivno značenje. Negativni kontekst liberalizma otežavajuća je okolnost pri poimanju odnosa Katoličke Crkve i države, a s druge se strane, s pozicije suvremene liberalne države, Newmanovo i Strossmayerovo shvaćanje povijesti, u čijem je središtu načelo Božje providnosti, tako- 
đer tako kvalificira, što istodobno Katoličku Crkvu čini konzistentnom i autentičnom, za razliku od suvremene liberalne države, koja često poprima utopijske i ideološke karakteristike. Upravo stoga ta se razlika redovito doimlje nepremostivom. Naposljetku, primjećujemo da se ta pitanja dodatno kompliciraju pogrješnom predodžbom Dogme o papinskoj nezabludivosti, koju se ne shvaća u duhu sklada savjesti i autoriteta.

Ključne riječi: John Henry Newman, Josip Juraj Strossmayer, Katolička Crkva, država, odnos 